\title{
A Place for Proletarians? \\ A Contextual Hypothesis on Social Space in Roman and Migration Period Long-Houses
}

\author{
Svante Norr
}

\begin{abstract}
In some Scandinavian long-houses from the Roman and Migration periods there has existed a small room between the byre and its nearest gable. Several factors make it likely that it was used for habitation. On the basis of a contextual analysis, it is suggested that it should be interpreted as housing land-less dependants of the estateowner.
\end{abstract}

Svante Norr, Department of Archaeology, Uppsala University, S-753 10 Uppsala, Sweden.

Nowadays, dozens of house foundations are added annually to the archaeological data in the Mälar valley alone, thereby corroborating a general and important increase in both theoretical and practical archaeological knowledge (e.g. Andersson et al. 1987, Andersson et al. 1994, Holm et al. 1993 and Aspeborg 1994). The 1992-94 investigations for the MIAB (Mälarbanans Intressenter $A B)$ part of the Mälarbanan railway project in southern Uppland and Västmanland alone contributed with at least 30 three-aisled houses and a handful of other buildings, the majority of which could be dated to the Iron Age and particularly to the Roman and Merovingian periods (Hulth \& Norr 1996 with refs.).

It might be assumed that this amassment of data has generated a corresponding increase in our understanding of houses and settlements in the region. This is, however, not the case. Almost ten years ago Hedman (1987) called for evaluation and synthesis, but to little avail it seems (in spite of Broberg 1994). Regrettably, too many excavation reports still appear stuck in the notion that amassment of data is an end in itself, while interpretation, contextualization and synthesis are something that should not intrude on the "neutral" description of archaeological remains or only enter the report as a slight "dash" in the beginning or the end (cf. Norr 1993). The Mälarbanan settlement report is designed with the explicit aim to stress, as far as possible, the interpretative nature of excavation and reporting in opposition to the bureaucratic and positivist tradition. In the following I intend to present a hypothesis concerning social space in longhouses, primarily based on the Mälarbanan material.

The two most extensive settlement excavations along the Mälarbanan took place at Uppsala in Tillberga parish, and Fågelbacken in Hubbo parish, both in Västmanland. On each site, remains were found of two partly coeval farmsteads dated to the late Roman and Migration periods. At Uppsala the houses formed two clusters lying ca. 60 $\mathrm{m}$ apart, whereas in Fågelbacken the two farms were quite adjacent. At the latter site, indications of bead manufacturing and fine metalwork at the more insignificant eastern farm have been suggested as to imply a patron - dependant (client) relationship, in which 
the western farm had control over the specialized production (metalwork, glass manufacture) at the other (Norr 1996).

Analyzing the room-division of longhouses is problematic. Especially on the "usual" unstratified sites of rescue archaeology, few of the criteria suggested as indicative on the basis of research excavations can be used (Sundkvist 1996). Nevertheless an analysis of, in particular, the spatial distribution of constructional elements (trestles, hearths, entrances, partition walls, stalls, and whatever there is to see) within a sufficiently large material and on a comparative basis will produce patterns which may reveal something about both general trends in house construction and local particularities.

Concerning generalities it appears, for instance, that the basic dwelling-room in all of Scandinavia was a two-span (three-trestle) module with the main hearth situated in the second span, counted from the gable (Fig. 1). Myhre has pointed out that this module has often been divided into two rooms with different functions (1980: 321ff., 467). The Mälarbanan material gives the same impression insofar as a room is conceived of as a conceptual unit, not - necessarily - as a physical unit (cf. Sundkvist 1996). There is no evidence of any partition walls separating the spans of the dwelling module in any of those houses, and in house Fb3 ( $a$, in Fig. 1) the absence of a door-post between the middle trestle and the presence of the same between each end trestle provide evidence against such a physical partition.

The distance between the trestles in the dwelling module has often been around 4 or $5 \mathrm{~m}$, and it seems plausible that this measurement can be translated to 8 or 10 ells. This module appears often to have been used also for secondary, three-trestle buildings. We can, perhaps, surmise that the module had evolved from an earlier, three-span module with half the trestle distance, such as is found in, for example, house A in Lunda, Västmanland (Holm et al. 1993: Pl. 1) and which was retained in the byre part of many late Roman period houses (Fig. 1; cf. e.g. Aspeborg 1994: Fig. 3). From this understanding of the dwelling module it can be tentatively suggested that its double occurrence in house $\mathrm{Fb} 5$ in Fågelbacken ( $b$, in Fig. 1) means that this building contained two households (Norr 1996; cf. Näsman 1983: 66).

\section{THE ROOM BEYOND THE BYRE}

The analysis of the room-division in the longhouses at Fågelbacken and Uppsala furthermore shows that some of them have had an additional room between the byre and its nearest gable. In the case of Ual, Fb3 and $\mathrm{Fb} 5$ (house 1 in Uppsala, house 3 in Fågelbacken, etc.) it is clear that the room has been equipped with a hearth (Fig. 1). In other houses the hearth may not have been preserved or has never existed at all, and the room is indicated by a greater span between the trestles than in the byre proper, as in $\mathrm{Ua} 10$ and $\mathrm{Fb} 10$ (if the western part is accepted as the byre section in the latter building). The span is quite uniform in size, around 3.2 $\mathrm{m}$ (disregarding the space between the last trestle and the gable), and the passage to the byre is often marked by a somewhat angularly placed trestle, most obvious in $\mathrm{Fb} 3$ and Fb10. In Ua5 a similar room may have been situated between the second or first trestle from the east and the straight eastern gable (Hulth \& Norr 1996).

Ua1 and Ua5 can be dated by homologies to the 4th century or the Migration period; Ua5 had ceased to exist around the year 500 or the first half of the 6th century AD, when the later house Ua7 was constructed (Norr 1996). That there was a partition wall between the byre and the easternmost room in Ua1 is clearly indicated by the phosphate mapping of the house, made on a $1 \mathrm{~m}$ grid (Sundkvist 1996). Six radiocarbon datings of samples from the outer parts of remains of trestle posts in $\mathrm{Fb} 3$ and $\mathrm{Fb} 10$ were analysed as a group, showing correspondence with the 


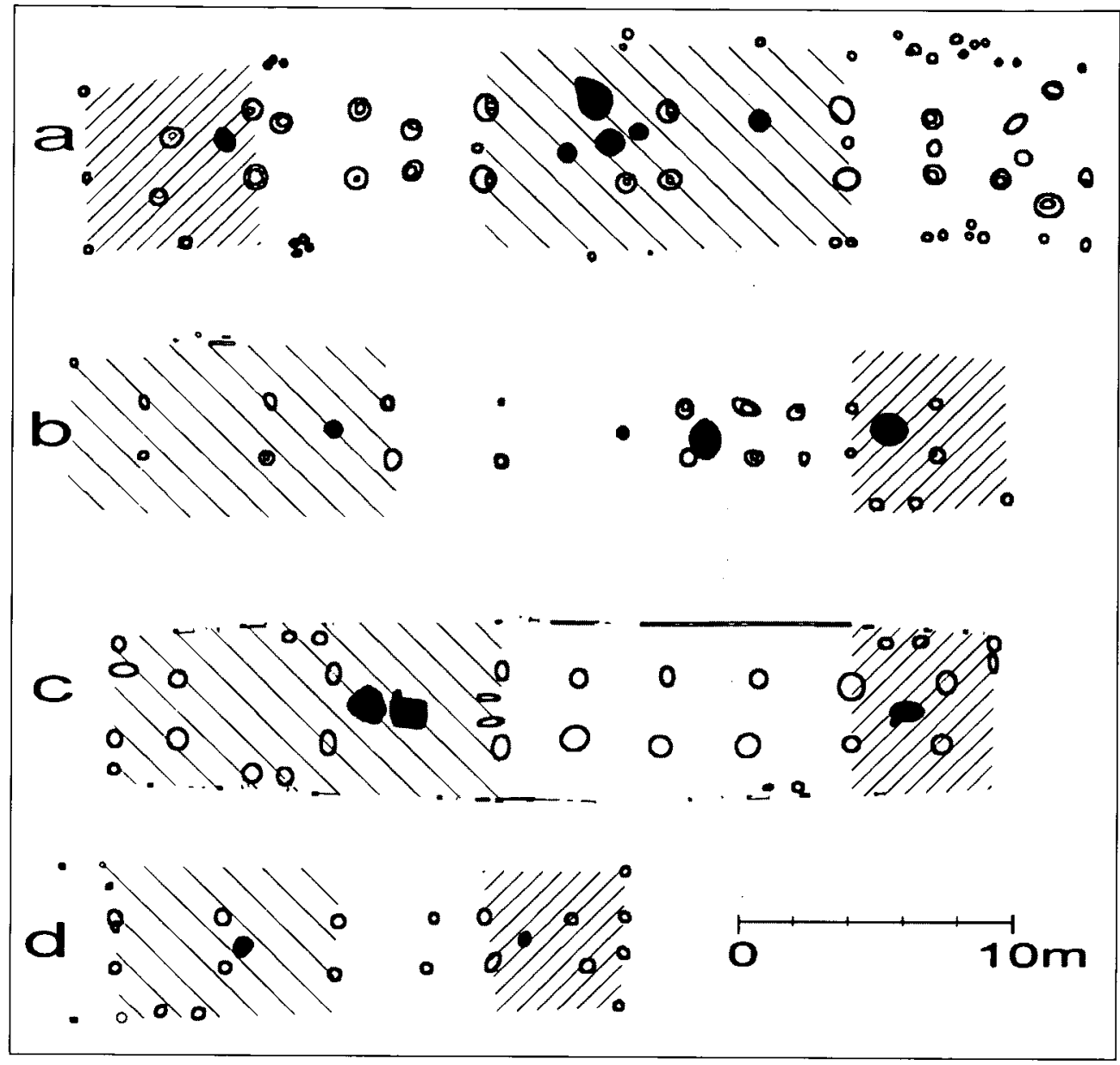

Fig. 1. Long-houses from the late Roman ( $b$ and $c$ ) and Migration ( $a$ and $d$ ) periods. Hatching = dwelling-room module; fine hatching = extra room. $a$-b: houses Fb3 and Fb5, Fågelbacken, Västmanland; : house III, Forsandmoen, digitized from Løken 1983: Fig. 4; d: house Ual, Uppsala, Västmanland.

calibration curve for the period 205-305 AD. The houses can therefore have been constructed at the earliest around 300 AD (Hulth \& Norr 1996; cf. Herschend 1994 on the method). Since a further ${ }^{14} \mathrm{C}$ sample on charred seeds from the later house, $\mathrm{Fb} 3$, indicated a date in the 6 th century, this was most likely a Migration period construction. The interpretation of the room-division of $\mathrm{Fb} 3$ was facilitated by the occurrence of traces of door-posts between some trestles (Fig. 1). The very light post-hole fill of Fb5 showed that this house pre-dated $\mathrm{Fb} 3$ and $\mathrm{FblO}$, and it was therefore probably constructed in the late Roman period. Ualo was of the same type as Fb5, and a ${ }^{14} \mathrm{C}$-analysis confirms a dating to the late Roman period (Norr 1996).

In Denmark similar rooms beyond the 
byre are well known from Jutish houses in Vorbasse, Nørre Snede, Løgumkloster, Mørup, Sjælborg and Grønbjerg - here also characterized by a greater distance between the trestles than in the byre itself. In Nørre Snede they occur in 27-37 $\mathrm{m}$ long houses and are 5-9 $\mathrm{m}$ long. In Vorbasse they are also occasionally found in smaller long-houses (Thomsen 1959:15; Hvass 1979:70, 73; Hansen 1987:177 with refs.). The house at L $\varnothing-$ gumkloster is the only one in which a hearth has been preserved in this room (Andersen \& Rieck 1984: Fig. 3). In no case has there been any indications as to what function the room may have had (Hansen 1987:177; Hvass 1991:70). Myhre (1980:438) has suggested that already house I in Hodde may have had such an additional room in its phase 1, but as Hvass has shown (1985:113) it is merely that the byre was longer.

In houses I and II in Gene, Angermanland, the area beyond the byre was, according to Ramqvist, taken up by a storage room and a cooking room (closest to the gable). In house I the distribution of carbonized seeds (particularly concentrations of fat hen and nettle) indicates that this northernmost part was "primarily occupied by man" (Ramqvist 1983:155). In house II a hearth was certainly situated in the "cooking" room, and this may have been the case also in house I. Both houses had an entrance to the "cooking" room (Ramqvist 1983: Fig. 5:12). Gene I shows striking constructional similarities to $\mathrm{Fb} 3$, and a re-calibration and re-interpretation of the ${ }^{14} \mathrm{C}$ sequences from Gene has, in fact, shown that the houses were more or less contemporaneous; Gene I was, contrary to Ramqvist (1983:184), constructed not earlier than in the 4th century (Norr 1996).

In Norway an extra room with a hearth is seen in house III in Forsandmoen ( $c$, in Fig. 1), where we also find a separate entrance as well as in the very long (c. $51 \mathrm{~m}$ ) house from the same site in fig. 1B in L $\emptyset$ ken 1992 (where the room may comprise four spans). Yet another example is found in house 15 in
Skälby, Västmanland, where the hearth, but no wall- or entrance-posts, was preserved (Aspeborg 1994: Fig. 3). In Skavsta II, Södermanland, the room is marked by the post setting only (Olausson 1992: Fig. 8), and the same applies to the house from Nyckelby, Uppland (Göthberg 1989: Fig. 2).

\section{THE SOCIAL CONTEXT}

Without delving into chronological particularities, all these houses seem to date from the 2 nd century to the end of the Migration period. In other words, the phenomenon of the extra room appears to be connected with that major shift in the material expression of the home to which the material bears witness, most strikingly in Denmark but also in the Mälar valley. The trestle width has decreased, larger spans open up the interior (most notably in the living area), extra rooms have been added, and so forth. The house as social space has by and large become more complex.

In Denmark this occurs when the archaeological material conveys a picture of major and, in the archaeological perspective, sudden social change. The great bog sacrifices and lavish funerary monuments and gifts sharply contrast with the material expressions of the preceding period, and bear witness to turbulent times in which different elite groups compete for power and the control of vital resources by force of arms and the ritual consumption of wealth. Signs of a nascent central power (or powers) emerge, where local rulers lead permanent, armed entourages which to a large degree are supplied with Roman arms (Parker Pearson 1985: 80ff.; Hedeager 1988:201ff.).

At this time also decisive and welldocumented changes occur in settlement structure and organization. In the villages the common fence disappears, and the individuality of each farm thus appears to be accentuated rather than the collective of the village community. It is also evident that the smallest category of farms of the late pre- 
Roman and early Roman periods has ceased to exist, and instead the individual farms (production units) have grown larger. Land and property has, accordingly, become concentrated to fewer households, and many people have lost their rights to landownership entirely. Such unfortunate people must have been amalgamated into remaining households as dependants or perhaps even serfs (Hedeager 1988: 201). As a sign of this increased social inequality and - at least latent - tension, the material expression of the home undergoes changes as well, becoming more complex. The long-houses grow larger and the number of rooms increases; also, new building techniques are introduced (Herschend 1989; Hansen et al. 1991). We have reached a level of social, economic and ideological development where social inequalities are no longer (and need no longer be) euphemized by an egalitarian structuring of the home. Now, also, the phenomenon of the hall is introduced on the social scene (Herschend 1993).

It appears that we can see a corresponding, albeit not identical, development in northern Germany and Holland (Haarnagel 1979:319; Zimmermann 1992:46ff., 139; Brabandt 1993:61ff.). Here, however, the increased social complexity and inequalities are most often made manifest in other ways than through the invention of a room beyond the byre. The tradition of situating the byre entrance in the gable offers one logical explanation of this fact. At times it occurs, though, as in the type 2 (and occasional type ld) long-houses of Flögeln-Eekhöltjen, dating from the 1 st to the 3 rd century AD (Schmid \& Zimmermann 1976:35ff.). A phosphate mapping of house 14 at this site reveals the same pattern as the one in house Ual mentioned above, namely high levels in the byre and low ones between its last trestle and the gable (Zimmermann 1992:102, 126 and Abb. 15, 41,83).

Geographical and demographical differences naturally invite caution when project- ing the Danish (or German) situation on the contemporaneous Mälar valley. But although here we have (as yet) no counterpart to the Danish picture, this is not to say that there were no structural parallels at all. It is likely that development here followed the same general course, but that it was more gradual and diversified, as becomes a more peripheral area.

\section{THE ROOM CONTEXTUALIZED}

Against this background the hypothesis can be put forth that the extra room beyond the byre can be explained in the same social terms in all of Scandinavia. To be more specific, I suggest that it is an additional living-room used by land-less (and perhaps entirely property-less) dependants of the house- and landowners. If the sketch of Danish events is principally valid also for the Mälar valley (which, I admit, cannot be proven), this room is an expression of the increased social inequalities caused by the gradual concentration of land and wealth to fewer owners, and providing a social space for those who "fell out" of the competitive system (or never entered the game, if we prefer to seek the cause in a population increase). By attatching themselves and offering their labour to remaining landowners, they gained the safety of a new tie to a household in exchange for the one they had lost through their proletarization. It would be logical if burial rights were part of such a deal.

This hypothesis rests on the assumption that functionalist explanations, for example, that constructional differences or changes mainly reflect differences or changes in the subsistence pattern (e.g. Brabandt 1993:6I ff.), fail to capture the complexity and dynamics of material culture as a social phenomenon. It acknowledges the ideological and intentional nature of social space as manifested in internal settlement structure or the home (cf. e.g. Donley 1982; Welinder 1992:49ff.).

Perhaps we encounter a woman of "proletarian" status in the tale of the Gothic mar- 
tyr St. Sabas (d. 372), himself a free man but poor, lacking property as well as social influence (Martyrdom 3; cf. Thompson 1966: 53). After Sabas had been tortured by his heathen prosecutors and left outside at night, tied to the axle of a wagon, this "woman, who had risen in the night to cook for those who were staying in the house, came up and released him. After he was set free, he remained in the place without fear and helped the woman in her work. In the morning, when the ungodly Atharidos got to know this, he ordered that he should be tied up and suspended from the roof-beam" (Martyrdom 5). The woman was obviously attatched to a household and was preparing the morning meal for its sleeping masters. Part of the woman's work may have been conducted outdoors, but it is logical that Sabas was found and bound inside the house, where there was a ready-to-hand roof-beam from which to suspend him. Heather \& Matthews draw the obvious conclusion that the woman may have been "a slave or servant of a leading household of the village" (1991:115, note 33 ). The recorded circumstances furthermore make it likely that her quarters were separated from those of her masters. This takes us far from the picture of Germanic society presented by Tacitus, in which even a slave was supposed to have had "control of a holding and home of his own", merely supplying his master with "a stated quantity of grain, live-stock or cloth" (Germania 25), as indeed it should. The breakdown of the old social order has reached a point where inequalities are no longer masked by social space.

\section{CONCLUSION}

It would be revitalizing if the dynamics of social life started to appear more frequently on the research agenda of Swedish settlement archaeology. I have suggested one way in which a social contradiction can be read into the seeming commonality and concordance of the space within long-house walls. The household, this unifying concept, may in fact be a cover for social domination and class conflict. As another example, I have already referred to the possible patron - client relationship between the two farms at Fågelbacken. Those who wish may substitute class for gender and get no worse a starting-point.

And what about my hypothesis? Well, the presented extracts from the documentary record can merely serve as an illustration, not a proper support. It is also evident that it will be difficult to gain empirical evidence for or against it, particularly in the context of everyday rescue archaeology (a diversified investigation strategy with intensive documentation of selected, well-preserved house foundations and a more extensive treatment of others could, however, take us somewhere). The initiated reader will already have made the silent remark that the open eastern gable of some Danish houses argues against a too generalizing interpretation of the room in question (cf. Hvass 1976: 41). Furthermore, additional rooms in some late Roman and Migration Period house foundations in southern Norway, for example Vaula 1 and Hodnefjell 2, may still appear more readily interpreted in functional terms, as smithies or secondary byres (Myhre 1980: Figs. 164, 172; 1982:172). If, however, the hypothesis should prove to have some validity, it is interesting to note that the extra room occurs in houses of varying sizes in our Mälar valley material, from the only $20.9 \mathrm{~m}$ long Ual to the $36.5 \mathrm{~m}$ long $\mathrm{Fb} 3$. The conclusion would be that already in the 4 th and 5 th centuries proletarization was a fairly widespread social phenomenon in the region. The position of the extra room beyond the byre can then be construed as a material expression of the relational position and status of its inhabitants: they were an extension of the household proper, in the same way as the room itself was an extension of the classical, dwelling-byre house.

English revised by Laura Wrang. 


\section{REFERENCES}

Andersen, S. W. \& Rieck, F. 1984. Mølleparken. A Settlement of the Fourth/Fifth Centuries $\mathrm{AD}$ at Løgumkloster, South Jutland. Journal of Danish Archaeology, vol. 3, 1984:170-176. Odense.

Andersson, K., Göthberg, H., Hjärthner-Holdar, E., Karlenby, L. \& Söderberg, S. 1987. E18projektet. Preliminära undersökningsresultat frăn 1986. Tor, vol. 21:17-56. Uppsala.

Andersson, K., Biwall, A., Frölund, P., Holm, J., Rosborg, B., Waks, B.-G. \& Wrang, L. 1994. Tibble - bebyggelse och gravar i norra Trögden. Arkeologi pằ väg - undersökningar för E18. Riksantikvarieämbetet, UV-Uppsala, Rapport 1994:52. Stockholm.

Aspeborg, H. 1994. Den arkeologiska undersökningen i Västra Skälby. In: Om forntid och medeltid i Västmanland. Västmanlands Fornminnesförening och Västmanlands Läns Museum. Årsskrift 71:53-61. Västerås.

Brabandt, J. 1993. Hausbefunde der römischen Kaiserzeit im freien Germanien. Ein Forschungsstand. Veröffentlichungen des Landesamtes für archäologische Denkmalpflege Sachsen-Anhalt, Landesmuseum für Vorgeschichte, Band 46. Halle (Saale).

Broberg, A. 1994. Mellansvensk bebyggelsearkeologi. En forskningsöversikt med blicken riktad mot 90-talets uppdragsarkeologi. In: O. Kyhlberg (ed.), Arkeologi i Attundaland. Studier från UV Stockholm. Riksantikvarieämbetet Arkeologiska undersökningar, Skrifter nr 4:32-51. Stockholm.

Donley, L. 1982. House power: Swahili space and symbolic markers. In: I. Hodder (ed.), Symbolic and Structural Archaeology. Cambridge.

van Es, W.A. 1967. Wijster, a native village beyond the imperial frontier 150-425 AD. Paleohistoria 11, 2 Bde. Groningen.

Flemberg, J. 1992. The Martyrdom of Saint Sabas the Goth, translated into Swedish and English. Tor, vol. 24:165-175. Uppsala.

Germania $=$ Tacitus, The Agricola and the Germania, translated by H. Mattingly (transl. revised by S.A. Handford). 1966.

Göthberg, H. 1989. Järnåldershus i sydvästra Uppland. Tor, vol. 22: 61-78. Uppsala.

Haarnagel, W. 1979. Die Grabung Feddersen Wierde. Methode, Hausbau, Siedlungs- und
Wirtschaftsformen sowie Sozialstruktur. Feddersen Wierde 2. Wiesbaden.

Hansen, T. E. 1987. Die eisenzeitliche Siedlung bei Nørre Snede, Mitteljütland. Vorläufiger Bericht. Acta Archaeologica 58:171-200. København.

Hansen, T., Hvass, S., Mikkelsen, D. 1991. Landsbebyggelser $\mathrm{i}$ 7. århundrede. In: P. Mortensen \& B.M. Rasmussen (eds.), Fra Stamme til Stat $i$ Danmark 2: Høvdingesamfund og Kongemakt. Jysk Arkæologisk Selskabs Skrifter XXII:2. Aarhus.

Heather, P. \& Matthews, J. 1991. The Goths in the Fourth Century. Liverpool.

Hedeager, L. 1992. Danmarks jernalder. Mellem stamme og stat. Aarhus.

Hedman, A. 1987. Östra Mellansveriges järnåldersboplatser. In: 7000 år på 20 år. Arkeologiska undersökningar i Mellansverige: 131 142. Stockholm.

Herschend, F. 1989. Changing houses. Early medieval house types in Sweden 500 to 1100 AD. Tor, vol. 22: 79-103. Uppsala.

- 1993. The Origin of the Hall in Southern Scandinavia. Tor, vol. 25: 175-200. Uppsala.

- 1994. Estimating the length of a period by means of ${ }^{1+}$ C-tests. Laborativ Arkeologi 7, Journal of Nordic Archaeological Science. Stockholm.

Holm, J., Wilson, L. \& Aspeborg, H. 1993. Järnåldersbyn vid Stenåldersgatan $i$ Västerås. Arkeologisk undersökning av en boplats, RÄ̈ 85I, I Lunda, Badelunda socken, Västmanland. Riksantikvarieämbetet och Statens Historiska Museer. Rapport UV 1993:7. Uppsala.

Hulth, H. \& Norr, S. (eds.), 1996 (forthcoming). Fyra järnåldersboplatser längs Mälarbanan. Tryckta rapporter från Arkeologikonsult $\mathrm{AB}$. Upplands-Väsby.

Hvass, S. 1976. Udgravningerne i Vorbasse. Mark og Montre, 1976: 38-52.

- 1979. Die Völkerwanderungszeitliche Siedlung Vorbasse, Mitteljütland. Acta Archaeologica 49:61-111. København.

- 1985. Hodde. Et vestjysk landsbysamfund fra aldre jernalder. Arkæologiske Studier, Volume VII. København.

- 1991. Jernalderens bebyggelse. In: P. Mortensen \& B.M. Rasmussen (eds.), Fra Stamme til Stat i Danmark, 1. Jernalderens stammesamfund. 
Jysk Arkæologisk Selskabs Skrifter XXII. Aarhus.

Løken, T. 1983. En ny type gårdsanlegg fra Fors i Rogaland. In: G. Ólafsson (ed.), Hus, gård och bebyggelse. Föredrag från det XVI nordiska arkeologmötet, Island 1982. Reykjavík. - 1992. Forsand og jernalderens landsbyanlegg i Rogaland - ressursbakgrunn og struktur. I: Gaird-tettsted - kaupang - by = N.U.B. Nr. 3 . Bergen.

Martyrdom = Flemberg, J. 1992.

Myhre, B. 1980. Gårdsanlegget på Ullandhaug I. Gärdshus $i$ jernalder og tidlig middelalder $i$ Sørvest-Norge. Ams-Skrifter 4. Stavanger.

- 1982. Settlements of Southwest Norway during the Roman and Migration Periods. Offa 39, pp. 197-215. Kiel.

Norr, S. 1993. Fältarkeologi på 90-talet. En provokation utifrån exemplet Klasro. Tor, vol. 25: 101-118. Uppsala.

- 1996 (forthcoming). Much ado about housing: more than a summary. In: H. Hulth \& S. Norr (eds.), Fyra järnåldersboplatser längs Mälarbanan. Tryckta rapporter från Arkeologikonsult AB. Upplands-Väsby.

Näsman, U. 1983. Review of B. Myhre, Gårdsanlegget på Ullandhaug I. Nonvegian Archaeological Review, vol. 16, no. 1: 62-67.

Parker Pearson, M. 1985. Economic and ideological change: Cyclical growth in the pre-state societies of Jutland. In: D. Miller \& C. Tilley (eds.), Ideology, power and prehistory: 69-92. Cambridge.

Olausson, M. 1992. Skavsta. Två gårdar från äldre järnålder vid Nyköpings flygplats. Riksantikvarieämbetet och Statens historiska mu- seer, rapport, UV 1992:6. Stockholm.

Ramqvist, P. 1983. Gene. On the origin, function and development of sedentary iron age settlement i northern Sweden. Archaeology and environment 1 . Umeå.

Schmid, P. \& Zimmermann, W. H. 1976. Flögeln. Zur Struktur einer Siedlung des 1. bis 5. Jhs. n. Chr. im Küstengebiet der südl. Nordsee. Probleme der Küstenforschung im südlichen Nordseegebiet 11. Hildesheim.

Sundkvist, A. 1996 (forthcoming). Rumsindelning: Mer än att identifiera mellanväggar. In: H. Hulth \& S. Norr (eds.), Fyra järnåldersboplatser längs Mälarbanan. Tryckta rapporter från Arkeologikonsult $\mathrm{AB}$. UpplandsVäsby.

Thompson, E. A. 1966. The Visigoths in the Time of Ulfila. Oxford.

Thomsen, N. 1959. Hus og kjælder i romersk jernalder. Kuml 1959: 13-27.

Weinmann, C. 1994. Der Hausbau in Skandinavien vom Neolithikum bis zum Mittelalter. Mit einem Beitrag zurinterdiziplinären Sachkulturforschung für das mittelalterliche Island. Quellen und Forschungen zur Sprach- und Kulturgeschichte der germanischen Völker 106 (230). Berlin \& New York.

Welinder, S. 1992. Människor och artefaktmönster. Occasional Papers in Archaeology 5. Uppsala.

Zimmermann, W. H. 1992. Die Siedlungen des 1. bis 6. Jahrhunderts nach Christus von FlögelnEekhöltjen, Niedersachsen: Die Bauformen und ihre Funktionen. Probleme der Küstenforschung im südlichen Nordseegebiet, Band 19. Wilhelmshaven. 